Counsellia: Jurnal Bimbingan dan Konseling, 10 (2), $2020 \mid 97-108$

Copyright @2020 Universitas PGRI Madiun

ISSN: 2088-3072 (Print) / 2477-5886 (Online)

Available online at: http://e-journal.unipma.ac.id/index.php/JBK

DOI: 10.25273/counsellia.v10i2.5144

\title{
Efektivitas Konseling Kelompok Ringkas Berfokus Solusi untuk mengembangkan konsep diri akademik Siswa
}

\author{
Sumini $^{1}$, Wahyu Nanda Eka Saputra ${ }^{2}$, Siti Partini Suardiman ${ }^{3}$ \\ ${ }^{1}$ Fakultas Keguruan dan Ilmu Pendidikan, Universitas Ahmad Dahlan, Yogyakarta \\ sumini1515001151@webmail.uad.ac.id \\ ${ }^{2}$ Fakultas Keguruan dan Ilmu Pendidikan, Universitas Ahmad Dahlan, Yogyakarta \\ wahyu.saputra@bk.uad.ac.id \\ ${ }^{3}$ Fakultas Keguruan dan Ilmu Pendidikan, Universitas Ahmad Dahlan, Yogyakarta \\ siti.partini@bk.uad.ac.id
}

\begin{abstract}
Abstrak
Penelitian dilakukan untuk mengetahui efektifitas konseling kelompok ringkas berfokus solusi guna mengembangkan konsep diri akademik siswa kelas VIII SMP Negeri 3 Tanjungsari tahun ajaran 2018/2019. Menggunakan jenis penelitian Eksperimen, dengan desain pre-eksperimen, model yang digunakan adalah One-group pretest posttest design. Subjek dipilih dengan teknik Nonprobability Sampling Design menggunakan Purposive Sampling. Pemilihan subjek didapatkan 6 siswa dari kelas VIII SMP Negeri 3 Tanjungsari, yang kategori dari nilai skala konsep diri akademiknya rendah. Teknik pengumpulan daya yang digunakan adalah skala konsep diri akademik dan pedoman wawancara. Data terkumpul dalam bentuk kuantitatif (angka). Analisis secara statistik dilakukan menggunakan rumus t-test. Hasil penelitian dapat disimpulkan bahwa ada perbedaan signifikan antara tingkat konsep diri akademik siswa sebelum dan setelah diberikan perlakuan yaitu layanan konseling kelompok ringkas berfokus solusi.
\end{abstract}

Kata kunci: Konsep Diri Akademik, Konseling Kelompok Ringkas Berfokus Solusi

\begin{abstract}
This study aims to determine the effectiveness of solutions focused group brief counseling to develop academic self-concept of class VIII students of Tanjungsari State Junior High School 3 academic year 2018/2019. The type of research used was Experiments with the Pre-Experimental Design using the One-group pretest posttest design. Determination of the subject uses the Nonprobability Sampling Design technique using Purposive Sampling. The subjects of this study were 6 students from 8th grade of Tanjungsari State Junior High School 3, with a category of low academic self-concept scale values. The power collection techniques used are the scale of academic self-concept and interview guidelines. Data collected in quantitative form (numbers) are then analyzed statistically using the t-test formula. The results showed a significant difference between the level of academic self-concept of students before and after being given a solution-focused group counseling treatment.
\end{abstract}

Keywords: Academic Self Concept, Solutions Focused Group Brief Counseling.

\section{PENDAHULUAN}

Sesuai dengan usia perkembangannya, peserta didik pada tingkatan Sekolah Menengah Pertama masuk ke dalam kategori masa remaja awal. Seorang remaja berada 
pada suatu periode dimana mereka mengalami transisi pada sebagian aspek penting pada perkembangannya menuju dewasa. Remaja adalah masa dimana mulainya seorang individu menetapkan identitas ego mereka. Erikson (dalam Muss, 1988) percaya bahwa untuk menjalin hubungan interpersonal yang intim dibutuhkan identitas ego yang jelas dalam artian individu harus sudah mengetahui siapa dirinya yang sebenarnya (Muuss, 1988). Sehingga dapat diketahui bahwa identitas ego merupakan pengetahuan mendalam seorang individu tentang dirinya.

Pengetahuan identitas ego ini sejalan dengan keharusan seseorang untuk memiliki konsep diri. Cara pandang tentang diri sendiri atau konsep diri secara positif akan berpengaruh pada pembentukan identitas ego serta menunjang pencapaian tugas perkembangan individu. Bagian dari konsep diri yang perlu ditanamkan pada masa remaja khususnya siswa SMP ini salah satunya adalah konsep diri akademik. Namun masih banyak remaja yang mengalami krisis identitas yang terjadi karena konsep diri mereka masih dalam keadaan labil, terkadang positif terkadang negatif (Sutoyo \& Rahman, 2013).

Demikianlah perlunya adanya peningkatan konsep diri positif pada pembentukan identitas diri remaja agar mereka mampu menyelesaikan tugas-tugas perkembangannya yaitu penerimaan gambaran fisiknya, penerimaan peran seksualnya, kemandirian akan ekomoninya, dan konsep terhadap keterampilan dalam pendidikan (Hurlock, 2001). Konsep diri adalah hasil penilaian atau evaluasi individu terhadap dirinya berdasarkan pandangan orang lain mengenai pribadinya (Kiling \& Kiling, 2015). Sehingga konsep diri yaitu bagaimana seorang individu memandang dan menilai dirinya sendiri atas dasar evaluasi diri sendiri serta pendapat orang lain tentang dirinya. Sedangkan konsep diri akademik merupakan bagaimana individu memandang dan menilai dirinya terkait dengan kemampuannya dalam bidang akademik.

Selain konsep diri secara utuh, beberapa bagian yang lebih spesifik dari konsep diri yang memperngaruhi prestasi akademik peserta didik yaitu academic self-concept yang didalamnya ada verbal self-concept, school self-concept, math self-concept, dan lain sebagainya (Areepattamannil \& Freeman, 2008). Jika math self-concept seseorang tinggi maka mathematic motivation dan prestasi matematikanya juga akan tinggi (Martin \& Debus, 1998). Terdapat pengaruh konsep diri dan berpikir positif secara bersama-sama terhadap prestasi belajar matematika (Andinny, 2015). Dibandingkan dengan konsep diri fisik dan sosial, konsep diri akademik lebih signifikan berhubungan dengan prestasi akademik (Zahra et al., 2010).

Beberapa penelitian telah membuktikan bahwa konsep diri akademik menunjang kinerja akademik dan juga prestasi akademik yang lebih maksimal. Konsep diri akademik merupakan faktor penting dalam prestasi akademik remaja non-imigran dan imigran (Areepattamannil \& Freeman, 2008). Senada dengan itu, penelitian lain juga menunjukkan hubungan yang erat antara konsep diri akademik seseorang dikaitkan dengan kinerja akademiknya. Konsep diri akademik yang positif dapat digunakan untuk memprediksi kinerja baik dalam matematika dan sastra (Ghazvini, 2011). Argyle menyatakan bahwa konsep diri akademik dapat menjadi kurang positif jika dikairkan dengan keadaan perkembangan konsep diri, diantaranya reaksi dari lingkungan, membandingkan diri dengan orang lain, peranan seseorang serta identifikasi pada orang lain (Budiarsih \& Zen 2016).

Demikian pentingnya konsep diri akademik harus dimiliki oleh seorang peserta didik guna memaksimalkan kinerja akademik serta prestasi akademik. Namun sangat disayangkan pada kenyataannya di lapangan masih banyak siswa yang belum memiliki konsep diri akademik yang positif. Pada tahun 2013 masih terdapat 12,5\% atau sejumlah 10 siswa kelas X SMK Yapema Gadingrejo Lampung memiliki konsep diri yang rendah 
(Irawan, 2013). Hasil observasi pada tahun 2013 juga menunjukkan bahwa masih terdapat siswa kelas IX yang belum mempunyai konsep diri yang positif (Pramono, 2013). Konsep diri akademik yang masih rendah ternyata juga terdapat di sekolah tempat akan dilaksanakannya penelitian. Sesuai dengan hasil studi pendahuluan yang dilakukan pada siswa kelas VIII di SMP Negeri 3 Tanjungsari, membuktikan bahwa masih banyak siswa yang memiliki konsep diri akademik rendah. Hasil yang didapatkan dari 60 siswa, dengan kategori tinggi ada 7 siswa (11,67\%), sedang 40 siswa $(66,67 \%)$ dan rendah 13 siswa $(21,67 \%)$. Perbandingan jumlah siswa dengan kategori rendah dari dua kelas yang menjadi subjek studi pendahuluan yaitu 6 siswa dari kelas A dan 7 siswa dari kelas B. Studi pendahuluan ini menggunakan skala konsep diri akademik yang dikembangkan oleh Suharti untuk thesisnya guna mencapai gelar Master of Psychology di Universitas Ahmad Dahlan tahun 2016.

Konsep diri akademik menjadi bagian dari tugas perkembangan yang penting untuk dipenuhi oleh peserta didik. Peranan penting sangat dibutuhkan dari seorang guru BK atau konselor sekolah untuk mampu menjembatani perkembangan tersebut. Intervensi alternatif yang dapat diambil yaitu dengan menggunakan layanan konseling. Layanan konseling bersifat kuratif dan developmental artinya bahwa layanan konseling diberikan tidak hanya untuk mengentaskan masalah konseli namun juga untuk pengembangan (Myrick, 1993). Selama ini banyak layanan konseling yang cenderung mengarah kepada penggalian masalah dan penyebabnya dibandingkan dengan pencarian solusi (Fitriyah, 2014). Perlu adanya pendekatan konseling yang berfokus pada pembuatan atau pengarahan solusi. Layanan konseling bisa lebih singkat dan siswa lebih cepat dalam menumbuhkan konsep diri akademik mereka sekaligus dengan memanfaatkan sumber daya serta kekuatan dari dalam peserta didik. Pendekatan yang diyakini sesuai untuk mengembangkan konsep diri akademik yaitu konseling ringkas berfokus solusi atau juga dikenal sebagai solution-focused brief counseling (SFBC). Pendekatan ini dipilih karena asumsinya yang percaya setiap individu itu sehat, kompeten, dan mampu membangun solusi untuk mengubah dan meningkatkan kehidupan mereka menjadi lebih baik (Corey, 2015). Konseling ringkas berfokus solusi mengarahkan pembangunan solusi dengan meminimalisir dan menghapuskan faktor-faktor penyebab konsep diri akademiknya negatif.

Konsep diri akademik perlu ditingkatkan melalui suatu perubahan-perubahan langsung pada diri individu, sejalan dengan konsep konseling ringkas berfokus solusi yang meyakini perubahan yang kontinu akan mendukung pengembangan konsep dirinya kearah yang lebih positif. Selain itu pendekatan ini senantiasa percaya sebenarnya semua individu mempunyai solusi guna menyelesaikan permasalahannya namun terkadang lupa akan kompetensi mereka karena hanya selalu berkutat dan fokus pada permasalahanya (Corey, 2015). Keyakinan inilah yang selaras dengan keadaan seseorang dengan konsep diri akademik rendah, yang selalu merasa bahwa dirinya bermasalah namun tidak mencoba mencari solusinya.

Solusi yang muncul dari diri sendiri inilah yang diharapkan membuat peserta didik lebih berkomitmen untuk menerapkannya. Hal tersebut juga guna menunjang tujuan dari layanan bimbingan dan konseling sendiri dimana bukan untuk membuat peserta didik menjadi pecandu untuk menyelesaikan masalahnya bergantung pada konselor tetapi bagaimana untuk memandirikannya dengan menemukan solusi dari permasalahannya sendiri. Sehingga diharapkan peserta didik akan lebih mandiri dalam menghadapi permasalahannya dalam kehidupan mendatang. Hasil wawancara dengan guru BK/konselor sekolah menyatakan bahwa guru BK di SMP Negeri 3 Tanjungsari belum memanfaatkan konseling kelompok ringkas berfokus solusi guna mengembangkan konsep diri akademik siswa. 
Salah satu penelitian studi literatur sudah ada yang menawarkan konseling ringkas berfokus solusi guna menaikkan konsep diri akademik siswa (Nugroho dkk., 2018). Hasil beberapa penelitian juga sejalan menunjukkan bahwa konseling ringkas berfokus solusi berhasil diaplikasikan guna menyelesaikan berbagai masalah yang sejalan dengan konsep diri akademik. Keefektifan konseling kelompok ringkas berfokus solusi juga terbukti guna menurunkan kecemasan siswa dalam menghadapi ujian (Fithriana, 2014). Sejalan dengan keberhasilan tersebut konseling kelompok ringkas berfokus solusi pun efektif untuk meminimalisir perilaku agresif siswa SMA (Sari, 2014), meningkatkan disiplin diri siswa SMP (Arofah, 2015), serta meningkatkan percaya diri siswa secara efektif (Prabandari, 2015). Selaras, konseling ringkas berfokus solusi lebih efektif untuk meningkatkan motivasi berprestasi siswa dari keluarga broken home (Kusumaningrum, 2015) dan mengembangkan kemampuan pengendalian siswa terdahap compulsive internet use (Nurmalasari, 2016).

Konseling ringkas berfokus solusi percaya bahwa pada dasarnya semua manusia itu sehat, kompeten serta memiliki kemampuan untuk membangun solusi untuk permasalahan yang dihadapinya untuk meningkatkan kehidupannya (Corey, 2015). Proses konseling kelompok ringkas berfokus solusi memanfaatkan dinamika dalam kelompok untuk saling memberikan pendapat dan masukan guna menemukan berbagai macam solusi yang dapat diterapkan. Berdasarkan latar belakang masalah di atas maka peneliti bermaksud untuk mengetahui efektivitas layanan konseling ringkas berfokus solusi untuk mengembangkan konsep diri akademik pada siswa kelas VIII SMP Negeri 3 Tanjungsari tahun ajaran 2018/2019.

\section{METODE PENELITIAN}

\section{Rancangan Penelitian}

Jenis penelitian yang digunakan adalah eksperimen guna mengetahui hubungan sebab akibat serta pengaruh konseling ringkas berfokus solusi terhadap konsep diri akademik pada siswa kelas VIII SMP Negeri 3 Tanjungasi tahun ajaran 2018/2019. Memilih bentuk desain pre-eksperimen peneliti menggunakan model one group PretestPosttest design. Penelitian dilakukan pada satu kelas eksperimen tanpa kelas control (Sukmadinata, 2012).

\section{Instrumen Penelitian}

Instrumen yang digunakan dalam penelitian ini ada dua bentuk yaitu skala konsep diri akademik dan pedoman wawancara. Skala konsep diri akademik terdiri dari 43 butir pernyataan yang sudah tervalidasi. Uji reliabilitas menunjukkan koefisien 0,927 yang berarti memiliki kategori tingkat reliabilitas yang sangat tinggi. Pedoman wawancara digunakan pasca perlakuan dan posttest. Pedoman wawancara dirancang sesuai dengan setiap butir indikator pada teori konsep diri akademik yang diutarakan oleh Liu dan Wang (2005). Liu dan Wang menyatakan bahwa aspek konsep diri akademik ada dua yaitu keyakinan akademik dan upaya akademik (Liu \& Wang, 2005) yang kemudian dijabarkan menjadi, perasaan siswa tentang potensi akademik mereka, persepsi siswa tentang potensi akademik mereka, komitmen siswa, keterlibatan siswa dan kepentingan dalam tugas sekolah.

\section{Prosedur Pengumpulan Data}

Skala konsep diri akademik yang dikembangkan oleh Suharti digunakan untuk mengidentifikasi permasalahan awal pada siswa. Skala dibagikan pada siswa kelas VIII SMP Negeri 3 Tanjungsari di Kabupaten Gunungkidul. Peneliti lantas mengembangkan 
sendiri skala konsep diri akademik yang selanjutnya dibagikan sebagai bentuk prettest sesudah dinyatakan valid dan realiabel.

\section{Teknik Analisis Data}

Teknik analisis data kuantitatif digunakan dengan cara mendeskripsikan tingkatan konsep diri akademik siswa kelas VIII SMP Negeri 3 Tanjungsari. Hasil di deskripsikan dalam pembagian tiga kategori yaitu rendah, sedang dan tinggi. Analisis data secara statisik menggunakan rumus t-test sepenuhnya dikerjakan dengan batuan program perangkat lunak SPSS (Statistical Package for Social Science) guna mengetahui ada tidaknya kenaikan kategori dari konsep diri akademik siswa yang mulanya rendah beserta pemecahan masalahnya.

\section{HASIL DAN PEMBAHASAN}

\section{Hasil Penelitian}

Hasil dari penelitian disampaikan dalam dua bagian. Hasil pertama adalah kenaikan hasil nilai skala konsep diri akademik dari pretest ke posttest, yang kedua ialah hasil uji signifikansi yang didapatkan dari penggunaan rumus $t$-test.

Hasil pertama yaitu kenaikan hasil nilai skala konsep diri akademik dari nilai pretest ke posttest. Data hasil nilai Pretest dan Posttest skala konsep diri akademik setelah proses pengumpulan lalu dianalisis dengan program perangkat lunak Microsoft excel, dengan hasil yang diperoleh dari 6 subjek disajikan pada table 1 .

Tabel 1. Deskripsi Nilai Konsep Diri Akademik Siswa Kelas VIII SMP Negeri 3

Tanjungsari

\begin{tabular}{|l|c|c|c|c|c|c|}
\hline \multirow{2}{*}{ No } & \multirow{2}{*}{ Subjek } & \multicolumn{4}{|c|}{ Skor dan Kategori } & \multirow{2}{*}{ Gain (d) } \\
\cline { 3 - 6 } & & \multicolumn{2}{|c|}{ Pretest } & \multicolumn{2}{|c|}{ Posttest } & \\
\hline 1 & SJK & 84 & Rendah & 142 & Tinggi & 58 \\
\hline 2 & VBPA & 75 & Rendah & 109 & Sedang & 34 \\
\hline 3 & AU & 73 & Rendah & 114 & Sedang & 41 \\
\hline 4 & ATW & 85 & Rendah & 139 & Tinggi & 54 \\
\hline 5 & DN & 84 & Rendah & 105 & Sedang & 21 \\
\hline 6 & ISW & 76 & Rendah & 100 & Sedang & 24 \\
\hline$\sum$ & N=6 & $\mathbf{4 7 7}$ & & $\mathbf{7 0 9}$ & & $\sum \mathbf{d = 2 3 2}$ \\
\hline \multicolumn{2}{|l}{ Mean } & $\mathbf{7 9 , 5}$ & & $\mathbf{1 1 8 , 1 7}$ & & $\mathbf{3 8 , 6 7}$ \\
\hline
\end{tabular}

Pada tabel 1 terlihat adanya kenaikan konsep diri akademik pada semua subjek. Berawal dari berkategori rendah, semua subjek mengalami kenaikan ke kategori sedang maupun tinggi. Rata-rata kenaikan nilai sebesar 38,67 poin. Sebelum adanya perlakukan, rata-rata nilai konsep diri akademik subjek adalah 79,5. Setelah adanya perlakuan, ratarata nilai konsep diri akademik siswa naik menjadi 118,17 . Terlihat pula kenaikan konsep diri akademik siswa paling besar ialah subjek berinisial SJK sebesar 58 poin. Sedangkan kenaikan nilai konsep diri akademik terkecil yaitu pada subjek berinisial DN sebesar 21 poin.

Secara visual peningkatan konsep diri akademik siswa kelas VIII SMP Negeri 3 Tanjungsari dapat dilihat pada gambar 1 . 


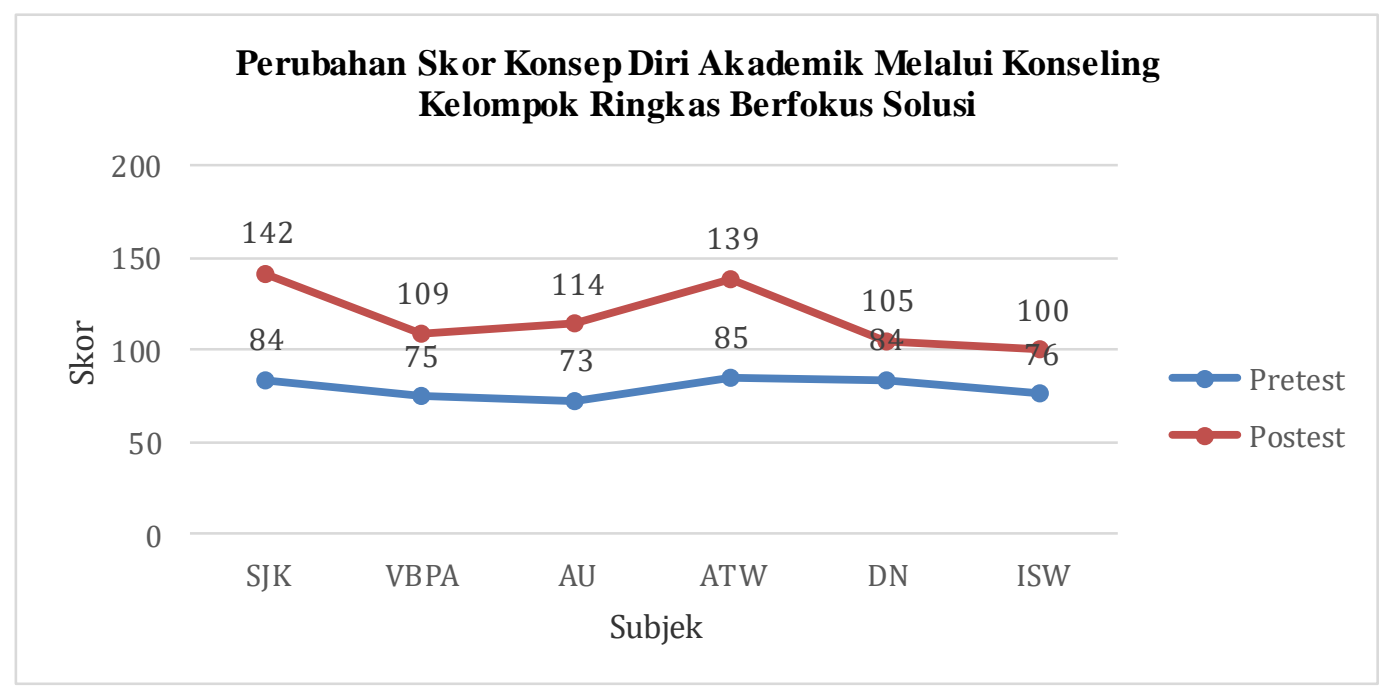

Grafik 1. Perubahan Nilai Konsep Diri Akademik Melalui Konseling Kelompok Ringkas Berfokus Solusi

Berdasarkan gambar grafik di atas bisa dilihat adanya peningkatan konsep diri akademik setelah subjek mengikuti rangkaian perlakuan. Hal ini dapat terlihat dari grafik berwarna merah yang merupakan hasil Posttest berada lebih tinggi dari grafik berwarna biru yaitu hasil Pretest. Gambar di atas dapat memberikan kesimpulan adanya peningkatan skor konsep diri akademik siswa sesudah dilaksanakannya layanan konseling kelompok ringkas berfokus solusi.

Hasil kedua yaitu hasil uji signifikansi, pada derajat bebas $(\mathrm{db})=\mathrm{n}-1=6-1=5$ dengan taraf signifikansi $(\alpha)=5 \%$ nilai $t_{\text {tabel }}=2,015$ sehingga Ho ditolak jika nilai $t_{\text {hitung }}$ $>\mathrm{t}$ tabel $(2,015)$ dan Ho diterima jika nilai $\mathrm{t}$ hitung $\leq 2,015$. Berdasarkan hasil uji $t$-test didapatkan nilai $\mathrm{t}$ hitung berada pada angka 6,209. Hasil perhitungan $t$ test diperoleh nilai $\mathrm{t}_{\text {hitung }}=6,027>2,015(\mathrm{t}$ tabel $)$ pada taraf signifikansi $(\alpha)=5 \%$ sehingga menunjukkan adanya peningkatan yang signifikan konsep diri akademik siswa setelah diberikan konseling kelompok ringkas berfokus solusi pada siswa kelas VIII SMP Negeri 3 Tanjungsari.

\section{Pembahasan}

Hasil penelitian ini menunjukan bahwa perlakuan yang diberikan yaitu layanan konseling kelompok ringkas berfokus solusi terbukti keefektifannya sehingga bisa digunakan sebagai alternatif pilihan layanan guna mengembangkan konsep diri akademik siswa. Konsep diri akademik sangat mempengaruhi hasil prestasi akademik maupun kinerja akademik siswa. Hal ini senada ada hubungan yang signifikan dan positif antara konsep diri dan prestasi akademik siswa di tingkat menengah atas (Kumari \& Chamundeswari, 2013). Konsep diri akademik juga lebih signifikan berhubungan dengan prestasi akademik dibandingkan dengan konsep diri fisik dan konsep diri sosial (Zahra dkk, 2010) maka penting bagi siswa untuk memiliki konsep diri akademik.

Konsep diri sendiri sejatinya merupakan keseluruhan gambaran terhadap diri sendiri. Gambaran diri ini meliputi persepsi, perasaan, keyakinan, serta nilai-nilai yang diyakini seseorang terkait dengan keadaan dirinya (Mar'at, 2009; Zahra dkk., 2010). Konsep diri juga disebutkan sebagai pikiran atau persepsi terhadap diri sendiri yang dikaitkan dengan statusnya di dunia luar (Kumari \& Chamundeswari, 2013) atau secara 
umum konsep diri mengacu kepada persepdi atau pandangan individu terhadap dirinya sendiri (Andinny, 2015). Pandangan terhadap diri sendiri dikaitkan dengan apa yang ingin diketahui dan dirasakan orang seseorang mengenai perilakunya, serta sebagai sikap, gambaran dan keyakinan tentang keseluruan dirinya. Pola inilah yang juga merupakan pola dari kepribadian (Mar'at, 2009).

Konsep diri akademik kemudian dijabarkan sebagai keseluruhan gambaran diri seseorang yang meliputi persepsi, keyakinan dan nilai-nilai tentang kemampuan diri dan perasaannya terhadap kehidupan akademik (Marsh dkk., 2005). Persepsi individu tentang dirinya dilihat dari perspektif sebagai pembelajar yang telah sering dijadikan sebagai predictor penting dari motivasi berprestasi dan kinerja akademiknya (Song \& Hattie, 1984). Sehingga konsep diri akademik dapat disimpulkan sebagai persepsi, pandangan, gambaran, nilai-nilai dan keyakinan seorang individu tentang dengan kemampuan dirinya, statusnya di dunia luar serta perasaannya terkait dengan keadaan akademik.

Konsep diri akademik dibagi menjadi dua aspek utama yaitu keyakinan akademik (Academic Confidence) dan upaya akademik (Academic Effort) (Liu \& Wang, 2005). Keyakinan akademik berhubungan dengan persepsi dan perasaan siswa terkait dengan kompetensi akademiknya. Sedangkan upaya akademik berhubungan dengan komitmennya, keterlibatannya serta kepentingannya dalam tugas-tugas sekolah misalnya bisa dikaitkan dengan mengikuti peraturan sekolah, tidak membolos dan mengerjakan tugas tepat waktu.

Konsep diri akademik bersifat dinamis, stabil, terus berkembang dan evaluatif sehingga bisa ditingkatkan dan diperbaiki sesuai dengan tujuannya (Soemanto, 2006). Pembentukan konsep diri sendiri secara umum lebih dominan dipengaruhi oleh faktor lingkungan yaitu orang lain dan grup acuan (Hutagalung, 2007). Maka, setiap individu harus dibekali rasa penerimaan diri yang benar agar mampu melihat dan membandingkan diri pada lingkungan dengan lebih positif. Sehingga pemilihan layanan konseling dalam format kelompok ini ditujukan untuk mendukung tercapainya sumbangsih antar individu untuk bisa saling mengkonfirmasi pandangannya dalam perannya sebagai bagian dari lingkungan.

Pendekatan konseling ringkas berfokus solusi bersifat konstruktivisme serta solution-talk atau berfokus pada pembangunan solusi. Pada penggunaan pendekatan konseling ini, konselor akan berfokus pada percakapan untuk membangun sebuah solusi sehingga tidak akan terlalu mendalami masalah yang dihadapi konseli. Mengutamakan adannya perubahan perilaku diyakini sebagai pendekatan paling efektif untuk meningkatkan kehidupan seseorang (Corey, 2015). Mulai dikembangkan pada tahun 80an, pendekatan ini meyakini bahwa setiap individu sebenarnya kompeten dalam menciptakan solusi bagi permasalahan mereka, namun terkadang mereka tidak memahami kemampuan ini karena hanya fokus terhadap permasalahan yang dihadapi tanpa mencoba mencari penyelesaiannya.

Konseling kelompok ringkas berfokus solusi ini dirancang dalam tujuh tahapan, yang pada kesemuanya dilakukan secara berurutan sesuai dengan tujuan yang ingin dicapai. Ketujuh tahapan tersebut terdiri dari Setting the Tone for the Group, Beginning to Set Goals, Searching for Exceptions to the Problem, Encouraging Motivation, Assisting Group Members With Task Development, The Next Group Session, dan Terminating (Corey, 2011). Karena setting yang digunakan adalah format kelompok sehingga hal utama yang harus dibangun dalam sesi konseling ialah menghidupkan suasana kelompok. Kenyamanan antar anggota dalam kelompok tentu sangat berpengaruh terhadap jalannya proses konseling. Saat perasaan dan kenyamanan semua anggota sudah bisa saling terhubung barulah bisa mulai kepada penentuan tujuan, penggunaan teknik konseling hingga akhirnya proses pengakhiran dan evaluasi. 
Konseling ini juga diperkuat dengan adanya beberapa teknik didalamnya. Teknikteknik dari konseling ringkas berfokus solusi yang digunakan dalam penelitian ini ada enam yaitu Exception-finding questions (Questions discovery exception), Miracle questions (Question miracle), Scaling questions (Question-scale), Pretherapy change, Formula first session task dan Therapist feedback to client. Penggunaan berbagai teknik ini bisa saling mendukung satu sama lain (Nugroho dkk., 2018).

Konseling ringkas berfokus solusi menjadi salah satu alternatif intervensi yang bisa dipilih oleh guru BK guna meningkatkan konsep diri akademik siswa. Pemilihan pendekatan konseling ringkas berfokus solusi ini didasarkan pada kesimambungannya dengan kondisi psikis konsep diri akademik seseorang. Konseling ini meyakini sebenarnya setiap orang mempunyai solusi guna menyelesaikan masalahnya sendiri hanya saja mereka sering lupa akan kompetensi yang dimilikinya karena selalu hanya berkutat dengan bentuk permasalahannya (Corey, 2015), hal ini selaras dengan kondisi seorang yang memiliki konsep diri akademik rendah. Individu dengan konsep diri rendah selalu merasa bahwa dirinya bermasalah namun tidak berusaha untuk mencari solusi. Pemberian perlakuan pada siswa dilatarbelakangi karena konsep konseling ringkas berfokus solusi meyakini perubahan yang berkesinambungan bisa mendukung siswa mengembangkan konsep dirinya kearah yang lebih positif (Corey, 2015).

Senada dengan hasil penelitian ini, konseling ringkas berfokus solusi pun dapat digunakan untuk meningkatkan motivasi berprestasi siswa yang berasal dari latar belakang keluarga yang bercerai (Kusumaningrum, 2015). Penelitian sebelumnya ini menggunakan true experimental design, dengan desain penelitian yang dipilih adalah pretest-posttest-control-group-design dengan subjek siswa kelas X di SMK N 2 Malang sebanyak 12 orang. Subjek yang diteliti hanya terfokus pada siswa yang memiliki latar belakang dari keluarga broken home dengan motivasi berprestasi rendah berbeda dengan penelitian ini yang menggunakan subjek semua siswa kelas VIII B SMP Negeri 3 Tanjungsari dengan berbagai latar belakang keluarga.

Hasil ini juga sejalan dengan penelitian yang dilakukan oleh Prabandari (2015) yang mampu meningkatkan percaya diri siswa secara efektif dengan pendekatan konseling ringkas berfokus solusi berdasarkan analisis menggunakan uji-t. Terdapat kenaikan yang signifikan antara sebelum dan setelah diberi perlakuan. Kenaikan tersebut menunjukkan bahwa layanan konseling ringkas berfokus solusi secara efektif dapat digunakan untuk meningkatkan kepercayaan diri siswa. Walaupun sama-sama menggunakan desain penelitian one-group pretest posttest namun penelitian Prabandari menggunakan skala percaya diri berbeda dengan penelitian ini yang memadukan antara skala konsep diri akademik dan diperkuat menggunakan hasil wawancara.

Penelitian yang dilakukan oleh Arofah (2015) dengan menggunakan desain pretest and posttest control group design dengan masing-masing grup beranggotakan 6 orang siswa SMP Negeri 5 memberikan hasil bahwa kelompok yang diberikan intervensi menggunakan pendekatan konseling ringkas berfokus solusi mendapatkan rata-rata lebih tinggi dibandingkan dengan kelompok kontrol yaitu yaitu $9.50>3.50$. Sehingga kesimpulan yang dapat diambil yaitu konseling kelompok ringkas berfokus solusi efektif untuk meningkatkan disiplin diri siswa SMP (Arofah, 2015). Berbeda dengan penelitian sebelumnya yang menggunakan pretest and posttest control group design, peneliti kali ini memilih one-group pretest posttest design dengan jumlah 6 subjek kelas VIII. Penelitian Arofah terfokus pada peningkatan disiplin siswa berbeda dengan penelitian ini yang memiliki fokus pada konsep diri akademik siswa.

Penelitian Sari (2014) pada tesis-nya juga telah menguji keefektivan konseling ringkas berfokus solusi untuk mengurangi perilaku agresif siswa SMA. Menggunakan model pretest and posttest control group design, penelitian ini mengambil subjek 5 orang 
siswa SMA (Sari, 2014). Penelitian lain dari Nurmalasari (2016) membuktikan pula bahwa konseling singkat berfokus solusi bisa digunakan untuk mengembangkan kemampuan siswa mengendalikan compulsive internet use (Nurmalasari, 2016). Hasil yang didapatkan oleh Nurmalasari dalam penelitiannya tersebut konseling ringkas berfokus solusi efektif digunakan mengembangkan kemampuan mengendalikan compulsive internet use hanya pada 3 dari 4 siswa sedangkan pada penelitian ini konseling ringkas berfokus solusi mampu meningkatkan konsep diri akademik pada 6 siswa yang diberikan layanan. Konseling ringkas berfokus solusi pun terbukti efektif digunakan untuk menurunkan kecemasan siswa dalam menghadapi ujian pada siswa SMP (Fithriana, 2014). Penelitian tersebut menggunakan bentuk rancangan penelitian yang digunakan adalah Baseline (A1)-Intervensi (B)-Baseline (A2). Analisis data menggunakan analisis data visual, dan analisis statistik uji wilcoxon matched-pairs signed-ranks test dengan memadukan hasil skala kecemasan, wawancara dan observasi.

Konsep bimbingan dan konseling Islam solution focused brief therapy (SFBT) efektif untuk membantu menangani perilaku prokrastinasi pada mahasiswa (Fernando \& Rahman 2016). Tujuan dari penelitian adalah untuk mengembangkan konsep bimbingan dan konseling Islam dipadukan dengan pendekatan ringkas berfokus solusi untuk menyembuhkan prokrastinasi pada mahasiswa. Akan tetapi penelitian ini belum menjelaskan secara rinci tahapan dan teknik yang digunakan dan terkesan mencampuradukkan antara teknik dan tahapan, berbeda dengan penelitian ini yang telah menjelaskan dengan rinci tahapan yang dilalui serta teknik yang digunakan dalam intevensinya serta terfokus hanya pada penggunaan pendekatan ringkas berfokus solusi tidak dikombinasikan dengan konseling Islami.

Penelitian ini juga mendukung hasil penelitian sebelumnya yang dilakukan oleh Hikmah (2016) yang berhasil membuktikan bahwa konseling ringkas berfokus solusi dalam setting kelompok juga efektif untuk meningkatkan self control siswa SMP 6 Cimahi dengan menggunakan desain penelitian kuasi eksperimen, berbeda dengan penelitian ini yang menggunakan desain penelitian pre-experimental design dengan fokus penelitian pada peningkatan konsep diri akademik siswa.

Penelitian lain menyimpulkan bahwa mengembangkan layanan konseling dengan memadukan antara pendekatan konseling ringkas berfokus solusi dengan seni kreatif yang kemudian dinamakan Creative Solution Focused Counseling Models (CSFCM) adalah strategi layak untuk mengembangkan Self-Regulated Learning Siswa (Saputra, Da Costa, \& Alhadi, 2018). Penelitian tersebut pada penelitian ini hanya menerapkan konseling ringkas berfokus solusi tanpa dibarengi dengan penggunaan seni kreatif serta perbedaan dalam fokus yang dikembangkan yaitu pada pengembangan konsep diri akademik bukan terkait self-regulated learning. Perbedaan dengan penelitian ini juga pada setting yang diterapkan yaitu menggunakan format kelompok dengan menggunakan tujuh tahapan bukan dengan setting individu dengan lima tahapan saja.

Berdasarkan banyak penelitian terdahulu yang telah membuktikan keefektifan pemberian layanan konseling ringkas berfokus solusi baik dengan setting individu maupun kelompok untuk mengatasi berbagai macam permasalahan pada konseli, tak terkecuali pula penelitian ini turut menyumbangkan bukti baru keefektifan konseling ringkas berfokus solusi dalam bidang lain, yaitu meningkatkan konsep diri akademik siswa. Dewasa ini sangat dibutuhkan sebuah intervensi yang dapat dengan cepat digunakan untuk menyelesaikan masalah dengan harus terus berkutat pada masalahnya. Pendekatan konseling ringkas berfokus solusi ini layak diterapkan, dengan fokus utama pada solution-talk dari pada problem-talk (Adiputra \& Saputra, 2015) diyakini lebih efektif untuk diterapkan dan dikembangkan untuk mengatasi berbagai macam masalah yang dihadapi oleh konseli. 


\section{SIMPULAN}

Setalah melakukan penilaian dan pengamatan didapatkan hasil kesimpulan berupa adanya kenaikan konsep diri akademik siswa setelah diberikannya rangkaian perlakuan dengan pemberian layanan konseling kelompok ringkas berfokus solusi. Dapat disimpulkan pula bahwa konseling kelompok dengan pendekatan ringkas berfokus solusi secara efektif dapat digunakan untuk mengembangkan konsep diri akademik pada siswa kelas VIII SMP Negeri 3 Tanjungsari, Gunungkidul. Bagi para peneliti pada bidang yang sama, disarankan untuk kedepannya dapat melakukan penelitian yang lebih mendalam. Bisa mengenai kemungkinan adanya faktor lain yang mempengaruhi konsep diri akademik individu selama diberikan layanan konseling kelompok ringkas berfokus solusi ataupun juga mengembangkannya dengan menggunakan pendekatan konseling yang lain agar konsep diri akademik siswa dapat dituntaskan secara optimal serta menyempurnakan penelitian yang telah dilaksanakan oleh peneliti.

\section{UCAPAN TERIMAKASIH}

Ucapan terimakasih kami sampaikan pada Program Studi Bimbingan dan Konseling Universitas Ahmad Dahlan yang telah memberi kesempatan untuk melakukan penelitian tentang penerapan konseling ringkas berfokus solusi untuk meningkatkan konsep diri akademik. Selain itu, para pembimbing penelitian juga memiliki peran signifikan terhadap pelaksanaan penelitian ini.

\section{DAFTAR PUSTAKA}

Adiputra, S., \& Saputra, W. N. E. (2015). Teori Dasar Konseling. Lampung: Aura Publishing.

Andinny, Y. (2015). Pengaruh konsep diri dan berpikir positif terhadap prestasi belajar matematika siswa. Formatif: Jurnal Ilmiah Pendidikan MIPA, 3(2).

Areepattamannil, S., \& Freeman, J. G. (2008). Academic achievement, academic selfconcept, and academic motivation of immigrant adolescents in the greater Toronto area secondary schools. Journal of Advanced Academics, 19(4), 700743.

Arofah, L. (2015). Keefektifan Konseling Kelompok Ringkas Berfokus Solusi untuk Meningkatkan Disiplin Diri Siswa SMP Negeri 5 Malang. DISERTASI Dan TESIS Program Pascasarjana UM.

Budiarsih, A. P., \& Zen, E. F. (2016). Studi Kasus Konsep Diri Siswa Sekolah Dasar. Jurnal Kajian Bimbingan Dan Konseling, 1(3), 112-117.

Corey, G. (2011). Theory and practice of group counseling. Nelson Education.

Corey, G. (2015). Theory and practice of counseling and psychotherapy. Nelson Education.

Elizabeth, B. H. (2001). Psikologi Perkembangan: Suatu pendekatan sepanjang rentang kehidupan (Edisi 5). Jakarta: Erlangga.

Fernando, F. \& Rahman, I. K. (2016). Konsep Bimbingan dan Konseling Islam Solution Focused Brief Therapy (SFBT) Untuk Membantu Menyembuhkan Perilaku Prokrastinasi Mahasiswa. JURNAL EDUKASI: Jurnal Bimbingan Konseling 2(2):215-236

Fithriana, F. (2014). Keefektivan Konseling Ringkas Berfokus Solusi Untuk Menurunkan Kecemasan Dalam Menghadapi Ujian Bagi Siswa SMP. DISERTASI Dan TESIS Program Pascasarjana UM.

Fitriyah, F. K. (n.d.). Program Studi Bimbingan dan Konseling Sekolah Pascasarjana Universitas Pendidikan Indonesia. 3. 
Ghazvini, S. D. (2011). Relationships between academic self-concept and academic performance in high school students. Procedia-Social and Behavioral Sciences, $15,1034-1039$.

Hikmah, N. (2016). Efektivitas Teknik Solution-Focused Brief Counseling (SFBC) dalam Setting Kelompok untuk Meningkatkan Self Control Siswa (PhD Thesis). Universitas Pendidikan Indonesia

Hutagalung, I. (2007). Pengembangan Kepribadian Tinjauan Praktis Menuju Pribadi Positif. Jakarta: Indeks.

Irawan, E. (2013). Efektivitas Teknik Bimbingan Kelompok Untuk Meningkatkan Konsep Diri Remaja (Studi Pre-Eksperimen Pada Siswa Kelas X SMK Yapema Gadingrejo Lampung). PSIKOPEDAGOGIA Jurnal Bimbingan Dan Konseling, 2(1), 44-54.

Kiling, B. N., \& Kiling, I. Y. (2015). Tinjauan Konsep Diri dan Dimensinya pada Anak dalam Masa Kanak-Kanak Akhir. Jurnal Psikologi Pendidikan Dan Konseling: Jurnal Kajian Psikologi Pendidikan Dan Bimbingan Konseling, 1(2), 116-124.

Kumari, A., \& Chamundeswari, S. (2013). Self-concept and academic achievement of students at the higher secondary level. Journal of Sociological Research, 4(2), $105-113$.

Kusumaningrum, S. A. (2015). Keefektifan Konseling Ringkas Berfokus Solusi untuk Meningkatkan Motivasi Berprestasi Siswa dari Keluarga Broken Home. SKRIPSI Jurusan Bimbingan Dan Konseling \& Psikologi-Fakultas Ilmu Pendidikan UM.

Liu, W. C., \& Wang, C. K. J. (2005). Academic self-concept: A cross-sectional study of grade and gender differences in a Singapore secondary school. Asia Pacific Education Review, 6(1), 20-27.

Mar'at, S. (2009). Desmita Psikologi Perkembangan. Bandung: Remaja Rosdakarya.

Marsh, H. W., Trautwein, U., Lüdtke, O., Köller, O., \& Baumert, J. (2005). Academic self-concept, interest, grades, and standardized test scores: Reciprocal effects models of causal ordering. Child Development, 76(2), 397-416.

Martin, A. J., \& Debus, R. L. (1998). Self-reports of mathematics self-concept and educational outcomes: The roles of ego-dimensions and self-consciousness. British Journal of Educational Psychology, 68(4), 517-535.

Muuss, R. E. (1988). Theories of adolescence. Crown Publishing Group/Random House.

Myrick, R. D. (n.d.). Developmental Guidance and Counseling-A practical approach. Retrieved January 22, 2019, from https://scholar.google.co.id/scholar?hl=en\&as_sdt=0\%2C5\&q=Robert+D.+Myric $\mathrm{k}+$ Developmental+Guidance+and+Counseling\&btnG $=$

Nugroho, A. H., Puspita, D. A., \& Mulawarman, M. (2018). Penerapan Solution-Focused Brief Counseling (SFBC) untuk Meningkatkan Konsep Diri Akademik Siswa. Bikotetik (Bimbingan Dan Konseling: Teori Dan Praktik), 2(1), 93-99.

Nurmalasari, Y. (2016). Konseling Singkat Berfokus Solusi dalam Mengembangkan Kemampuan Mengendalikan Compulsive Internet Use Siswa. EMPATI-Jurnal Bimbingan Dan Konseling, 3(2/Ok).

Prabandari, N. (2015). Keefektifan Penggunaan Model Konseling Ringkas Berfokus Solusi untuk Meningkatkan Percaya Diri Siswa Kelas VII di SMP Negeri 9 Malang. SKRIPSI Jurusan Bimbingan Dan Konseling \& Psikologi-Fakultas Ilmu Pendidikan UM.

Pramono, A. (2013). Pengembangan Model Bimbingan Kelompok Melalui Teknik Psikodrama untuk Mengembangkan Konsep diri Positif. Jurnal Bimbingan Konseling, 2(2). 
Saputra, W. N. E., Da Costa, A., \& Alhadi, S. (2018). Creative Solution Focused Counseling Models (CSFCM): Strategi Kreatif untuk Mengembangkan Selfregulated Learning Siswa. Jurnal Kajian Bimbingan Dan Konseling, 3(4), 162170.

Sari, D. K. (2014). Keefektivan Konseling Kelompok Ringkas Berfokus Solusi Untuk Mengurangi Perilaku Agresif Siswa SMA. DISERTASI Dan TESIS Program Pascasarjana UM.

Soemanto, W. (2006). Psikologi pendidikan. Jakarta: Rineka Cipta.

Song, I.-S., \& Hattie, J. (1984). Home environment, self-concept, and academic achievement: A causal modeling approach. Journal of Educational Psychology, 76(6), 1269.

Sukmadinata, N. S. (2012). Metode Penelitian Pendidikan" penelitian memberikan deskripsi, eksplanasi, prediksi, inovasi, dan juga dasar-dasar teoritis bagi pengembangan pendidikan. Bandung: PT Remaja Rosdakarya.

Sutoyo, A., \& Rahman, M. (2013). Pengembangan Model BK Kelompok Berbasis Islami untuk Peningkatan Konsep Diri. Jurnal Bimbingan Konseling, 2(1).

Zahra, A.-T., Arif, M. H., \& Yousuf, M. I. (2010). Relationship of Academic, Physical and Social Self-Concepts of Students with Their Academic Achievement. Contemporary Issues in Education Research, 3(3), 73-78. 